\title{
Need Analysis on English for Specific Purposes of Marketing Major Students
}

\author{
Wiranda Gusti Pratami \\ IAIN Bengkulu \\ wiranda2020@gmail.com \\ Syamsul Rizal \\ IAIN Bengkulu \\ syamsul.rizal42@gmail.com \\ Endang Haryanto \\ IAIN Bengkulu \\ haryantoendang95@gmail.com
}

\begin{abstract}
This study aims at determining the teaching materials needed by marketing students at SMKN 1 Kota Bengkulu and analyzing students' needs in learning English at SMKN 1 Kota Bengkulu. The subjects of this study were thirty four students of grade 10 students at SMKN 1 Kota Bengkulu. There were 34 students who participated in this research gathered by using purposive sampling The research method in this research was descriptive qualitative, and the instruments used in data collection were questionnaires, interviews and documentation. The results showed that teaching materials that have not been specific and English learning materials that are still general in nature, and ESP material have not yet available at SMKN 1 Kota Bengkulu. Second, the data indicated that the English language skill most needed by marketing students was speaking, and they claimed speaking was a useful skill to support their future work. In conclusion, this study recommends teachers at SMKN 1 Kota Bengkulu to pay more attention to the students 'needs in learning English as solution to improve their abilities in learning English.
\end{abstract}

Keywords:Learner's need, English for specific purposes, Need analysis.

\section{A. Introduction}

English Specific Purposes (ESP) is part of one of the applied linguistic sciences that refers to the teaching and learning process with the needs of students according to the context of their field. Therefore ESP is essential to understand the needs of students through the right content with the potential possessed by students. In addition, ESP provides more detailed instructions to teachers and students about the suitability of the learning context with the needs of students, which aims to explore information and student responses about the English textbooks they use. In short, the concept of ESP is a process of learning English with suitable content material in the teaching and learning process. 
However, ESP has not been implemented in the learning process. Teachers are more likely to use the English General Purposes (EGP) learning strategy, especially in Bengkulu. English General Purposes (EGP) refers to English education at the school level, where students are familiarized with the structural/grammatical elements of the English language to pass an exam. As a result, teachers do not teach material based on the context of their work. Instead, they teach material about empathy to students in English skills with nothing to do with their major. It happened because the teacher wanted to achieve the school's goal of passing the national English final exams.

To achieve the right ESP learning concept for students, the teaching materials used should have ESP criteria to understand it more easily. ESP has criteria, including ESP learning specifically designed based on scientific disciplines, ESP learning uses a different methodology from EGP, and ESP learning is generally designed for adult students, both at a higher level of education and in professional work situations.

Helen Basturkmen (2015) argues that ESP is not just discussing a job. In addition, ESP is learning with certain material content that refers to the integrity of students. English for Specific Purposes (ESP) prioritizes teaching and learning activities according to student needs and directly relates to understanding student work after graduation.

Thus, students will find it easier to understand the content of the existing materials if the teaching materials meet the ESP criteria scientific study. However, students must also understand the concept of scientific disciplines. In this case, students are less involved in developing English proficiency. Needs analysis is a process that is carried out systematically to obtain accurate data about the needs and desires of student learning (Casper, 2003). Thus, by analyzing the teacher's needs, the students can understand the weaknesses, strengths and potentials of students to increase student achievement and meet academic standards. Helen Basturkmen (2015) argues that ESP is not just discussing a job or scientific study, but students must also understand the concept of scientific disciplines. In addition, ESP is learning with certain material content that refers to the integrity of students.

Meanwhile, Tomlison (2011) said that textbooks are more likely to involve students in practice. Thus, when the learning practice takes place, textbooks are a source of reading for students and a source of knowledge extraction. The formation of English marketing textbooks can become learning materials for students to integrate their knowledge actively and independently. Thus, the researcher researched SMKN 01 Kota Bengkulu with 
the theme: Learner's Need Analysis of English for Specific Purposes Students Marketing of SMKN 1 Kota Bengkulu.

\section{B. Research Methodology}

The Researcher used a qualitative approach and a qualitative descriptive method. Descriptive research was a method that focused on describing the situation and condition in the research report. According to Cevilla (2014), descriptive research was a research method that described the status of a group of people. This method aims to determine a systematic, factual, and accurate description, object or painting about a fact or phenomenon.

In addition, Creswell (2015) defined qualitative research as an infrastructure to understand and explored individual human intentions or meanings related to social problems. The qualitative descriptive method is an actual measurable and reasonably accurate method because the results will be explained in detail. In this study of grade, the subjects were fortyfour 10th-grade students' of marketing major with totalling 34 students in the class. The participants in this research were collected using purposive sampling. In addition, this study focuses on the analysis of English learning need for students marketing at SMKN 1 Kota Bengkulu. Thus, The instruments in this research use questionnaires, interviews and documentation. The Researcher used the questioners to identify student needs. The Researcher will give a questionnaire to students marketing to conduct a needs analysis. The questions contained in the questionnaire are related to students' needs to deepen their English learning.

The interview was a method used for data collection where the interviewer gives questions to the person who wants to be an interview. The researcher also used documentation, a complementary instrument to support research to obtain accurate data. In the research, the researcher will analyze the data collected by the researcher use descriptive analysis. First, the authors discuss, describe, and analyze the collected data, then make conclusions based on existing phenomena — data analysis based on positivism and paradigm (Miles \& Hubberman, 2008, P. 308). There are several steps in analyzing the data. Data Reduction is made by summarizing field notes by separating main things relating to the research problem and then systematically describing and making accessible the data searching if it is sometimes needed. 
Data display is used to know the full description of the result either in from matrix or coding. If it has done by the researcher can take the conclusion and verify the meaningful data, and as the second step, the researcher has to consider what the researcher should do. Drawing and Verifying Conclusion used to conclude, namely using reduce and display data. Reduction and display of data logically will. After that, conclusions can be noted and need to be verified. The type of questionnaire refers to the needs analysis of Hutchinson and Waters (1987), Graves, and Nunan (2004). The model consists of two components, namely the target need and learning need.

1) Target needs,

This type of section only was needed to analyze what students need to do in the target situation. The target situation can be understood by looking at the components in the target situation, such as needs, shortcomings, and desires that need to be known from students. Needs means the needs expressed by the demands of the target situation, namely what students need to know to participate effectively in the target situation. Weakness means that there is a gap between the target and skills of students. Wants to refer to students' awareness of needs and shortcomings but cannot meet them due to conflicts with the perceptions of other interested parties: course designers, sponsors, and teachers;

a) Necessity

Type of need that was defined based on the target situation, namely what students need. The students were able to work effectively on target. For example, an entrepreneur must understand company papers, connect easily at a Sales convention, receive expected information from a Catalog sale, etc. He needs to know the features of linguistics discourse, structural, lexical, functional - and are used widely in the specified context.

b) Lacks

This need focused more on what we do not know about students to determine which criteria were passed from students. Existing skills need to be adapted to student skills. The difference between the two can be referred to as student deficiency.

c) Wants

Wants means what students expect or want to be based on their needs. The target situation only explains objectively what their needs are. One of the characteristics of the ESP situation was the awareness of students. Students certainly have insufficient insights. The students' perspectives will clash with the views of other parties. Student motivation in 
learning Should not be neglected based on the criteria for which the target needs can be obtained. These criteria can be seen through questionnaires, interviews, observations, and details.

\section{2) Learning Need}

Learning Needs were things that need to be done by students to learn. Hutchinson and Waters stated the definition of learning needs as an ability or knowledge needed by students to have exceptional skills in the target situation. This means that students were expected to have abilities based on their areas of expertise. Thus, to determine their learning needs, learning needs are divided into several parts, namely: input, procedures, settings, the role of students, the role of lecturers.

a) Input

According to Nunan, input refers to written, verbal and visual data used by students in completing a task. This means that input refers explicitly to oral, written and visual-based data obtained from various existing sources.

b) Procedure

Procedures serve to describe what students used with the material to achieve specific goals based on their area of expertise. This means that the procedure is made to find out an overview of learning English according to the needs of students.

c) Settings

Setting refers to the class used in teaching and learning activities (Nunan, 2004). The setting helps know whether students prefer a learning atmosphere outside the classroom or inside the classroom.

d) The role of the teacher

The teacher's role refers to the teacher's desired role by students in the teaching and learning process and social and interpersonal relationships between students (Nunan, 2004).

e) The role of students

The role of students refers to some of the parts that students expect in social relationships and learning and interpersonal tasks between students (Nunan, 2004). This means that the role of students wasto be able to complete learning tasks, build social or interpersonal relationships. 


\section{Results and Discussion}

\section{Results}

\section{a. Data from the questionnaire}

\begin{tabular}{|c|c|c|c|}
\hline No & Target Need Statements & Agree & Disagree \\
\hline \multicolumn{4}{|c|}{ Identification and Goal of student } \\
\hline 1. & $\begin{array}{l}\text { I learn English to improve my speaking } \\
\text { skills to my target market/consumers in } \\
\text { introducing products. }\end{array}$ & $88.2 \%$ & $11.8 \%$ \\
\hline \multicolumn{4}{|c|}{ Necessities } \\
\hline 2. & $\begin{array}{l}\text { I want to be proficient in learning English } \\
\text { so that I can apply it in marketing activities } \\
\text { at my company later. }\end{array}$ & $91.2 \%$ & $8.8 \%$ \\
\hline 3. & $\begin{array}{l}\text { I learn English to improve my English } \\
\text { communication skills to market products to } \\
\text { the international target market. }\end{array}$ & $100.0 \%$ & -- \\
\hline 4. & $\begin{array}{l}\text { I learn English to improve my speaking } \\
\text { skills because it is related to developing an } \\
\text { increasingly global marketing world. }\end{array}$ & $70.6 \%$ & $29.4 \%$ \\
\hline \multicolumn{2}{|r|}{ Score } & $87 \%$ & $18.6 \%$ \\
\hline \multicolumn{4}{|c|}{ Lacks } \\
\hline 5. & $\begin{array}{l}\text { I have difficulty understanding English } \\
\text { because the language used is not specific to } \\
\text { studying English which is applied in } \\
\text { marketing. }\end{array}$ & $58.8 \%$ & $41.2 \%$ \\
\hline 6. & $\begin{array}{l}\text { I am not interested in English material } \\
\text { because the teaching material is not related } \\
\text { to the field of marketing, such as Malin } \\
\text { Kundang storey and others. }\end{array}$ & $38.2 \%$ & $61.8 \%$ \\
\hline 7. & $\begin{array}{l}\text { I am not interested in learning English } \\
\text { because the book cover is not attractive. }\end{array}$ & $8.8 \%$ & $91.2 \%$ \\
\hline \multicolumn{2}{|r|}{\begin{tabular}{|c|} 
Score \\
\end{tabular}} & $35.3 \%$ & $64.7 \%$ \\
\hline \multicolumn{4}{|c|}{ Wants } \\
\hline 8. & $\begin{array}{l}\text { I can understand the proper use of } \\
\text { vocabulary and grammar in English books. }\end{array}$ & $76.5 \%$ & $23.5 \%$ \\
\hline
\end{tabular}




\begin{tabular}{|c|l|l|l|}
\hline 9. & $\begin{array}{l}\text { I can understand the four English skills } \\
\text { directly, namely listening, reading, writing } \\
\text { and speaking skills. }\end{array}$ & $70.6 \%$ & $29.4 \%$ \\
\hline 10 & $\begin{array}{l}\text { I can master the contents of the material, } \\
\text { such as vocabulary, grammar, pronouns } \\
\text { and others. }\end{array}$ & $58.8 \%$ & $41.2 \%$ \\
\hline \multicolumn{2}{|c}{ Score } & $\mathbf{6 8 . 6 \%}$ & $\mathbf{3 1 . 4 \%}$ \\
\hline
\end{tabular}

From 34 respondents consisting of two aspects, namely aspects of the target need and learning need. First aspects on the indicator of the Student's Goal as much as $88.2 \%$ of students want to improve their English speaking skills.

Furthermore, on the Necessity indicator, the highest $100 \%$ of respondents want to improve their English language skills to communicate when they are in the field directly. Then, on the Lacks indicator, the results show $58.8 \%$ of respondents have difficulty understanding English because the language used is not specific to the marketing department and $91.2 \%$ that students are interested in the cover and form of the book. In addition, the results show that $76.5 \%$ of students Want to and second on learning needs in the last indicator. Finally, the results show that $82.4 \%$ of students need an outdoor learning atmosphere and another $82.4 \%$ want a vibrant learning atmosphere in English, such as vocabulary and grammar in learning English.

\section{b. Learning Need}

\begin{tabular}{|l|l|c|c|}
\hline No & \multicolumn{1}{|c|}{ Learning Need } & Agree & Disagree \\
\hline \multicolumn{2}{|l|}{ Input } & $73.5 \%$ & $26.5 \%$ \\
\hline 11. & $\begin{array}{l}\text { I need original English materials such as } \\
\text { listening to films about trade and marketing. }\end{array}$ & $20.6 \%$ \\
\hline \multicolumn{2}{|l|}{ Procedure } \\
\hline 12. & $\begin{array}{l}\text { I am learning English to speak and have a } \\
\text { dialogue while doing the buying and selling } \\
\text { system to consumers using English. }\end{array}$ & $79.4 \%$ & $17.6 \%$ \\
\hline Setting & $82.4 \%$ & \begin{tabular}{l} 
\\
\hline 13.
\end{tabular} \\
\hline
\end{tabular}




\begin{tabular}{|c|c|c|c|}
\hline & $\begin{array}{l}\text { applied not only in schools but in the } \\
\text { surrounding environment. }\end{array}$ & & \\
\hline \multicolumn{4}{|c|}{ Teacher's Role } \\
\hline 14. & $\begin{array}{l}\text { English teacher can create a more vibrant } \\
\text { learning atmosphere in the marketing class. }\end{array}$ & $82.4 \%$ & $17.6 \%$ \\
\hline \multicolumn{4}{|c|}{ Learner's Role } \\
\hline 15. & $\begin{array}{l}\text { I am active in-class learning and able to discuss } \\
\text { in English }\end{array}$ & $73.5 \%$ & $26.5 \%$ \\
\hline
\end{tabular}

In the second aspect, namely learning needs, the results obtained from the questionnaire $73.5 \%$ of students require students to hope that learning media can be audiovisual such as watching movies and listening to music through television so that students have the opportunity to learn. New words and learn to improve their English skills.

Based on the results of the questionnaire regarding the aspects of the Procedure students need in their learning needs, the results obtained are $79.4 \%$ of students want to learn English directly in class with dialogue while discussing in class. To find out the need for further learning, the researcher discussed the Setting and the Role of the Teacher; the results obtained were that $82.4 \%$ were bored when learning English was only done indoors, and students expected learning English to be fun in the classroom where the teachers were required to create an atmosphere active and comfortable learning. Furthermore, the Role of the Teacher was as much as $82.4 \%$ of teachers are expected to be able to create a vibrant learning atmosphere in the classroom, such as during discussions and when the teacher explains the material in class. Moreover, in the last aspect, namely the Learner's Role, as many as $73.5 \%$ of students are pretty active in class.

\section{b. The Data from Interview}

The researcher finished using the questionnaire for the process of collecting data. The researcher also prepared research questions to support the data in this study. The researcher gave seven questions to the teacher, and 5 interviewed students. The interview is still non-structural regarding the opinions, needs and problems of students in learning English. 
First, the interview by researcher was a teacher who teaches 10th-grade students in marketing major at SMKN 1 Kota Bengkulu. According to him, the challenges for being an English teacher teaching for marketing students were the difficulty in conveying the contents of the material in the book due to the incomplete and orderly arrangement of the book material.

In addition, the internet is also one of the obstacles for him when giving assignments online. He also said that the method he most often uses in teaching English is discussing questions and answers to train students' abilities in the material he provides. In learning English, he provides an understanding of the four skills such as listening and speaking. He uses a book from the 2013 curriculum of the Ministry of Education and Culture.

Second, the interview was one of the students at marketing major. According to him, they got difficulty in learning English, particularly when discussing. He also said that he had trouble with English learning. For the ability to speak English, according to him, the most appropriate skill for his major is speaking to support their work in the future, such as doing business in the culinary and other fields.

Third, an interview was one of the students at marketing major. She is a 10thgrade students' marketing major. According to him, the situation of learning English is quite good. She also said that his weakness in learning English is the difficulty in understanding English learning materials. She argues that if the language used is relevant and unambiguous, it will be easy to understand. She views learning English as challenging to understand because the books used are still general. Then his opinion English is not complex if the material or language used is relevant and can be understood easily when read.

Fourth, the interview was one of the students at marketing major. She is a 10th-grade students' marketing major. She argues that English learning is challenging because the material is not structured and makes him confused when doing English assignments. She argues that English language skills are critical and needed for them as in speaking English. She can explore this ability by often listening to English songs or English films to increase their vocabulary.

Five, the interview was with one of the students at marketing major. She is a 10th-grade students' marketing major. She stated that learning English is quite good 
because the teacher also has an English dialogue between the teacher and students in addition to the Indonesian language. According to Dallas, what marketing students need is to understand English vocabulary and speak English because it is essential when they enter the world of work or business, which will affect the world of marketing.

The last interviewee was one of the students at marketing major. She said that the English material was still general and made it difficult for them to understand the four English skills. She has a view of the English language that is very important for the world of marketing. especially when they are discussing in English and

She stated that the situation of learning English is quite good. However, her view on English is that learning English will be easy to implement if they increase their vocabulary and improve their grammar. Therefore, the approach to using esp is very influential on the quality of a student's ability.

\section{Discussion}

ESP teachers have differences from English teachers in general. ESP includes needs analysis, material writing, adaptation, evaluation and syllabus design. They must design teaching materials based on the national syllabus. Nevertheless, it also includes student needs based on teacher needs analysis in preliminary activities. ESP is very concerned about aspects of students, especially for those who have professionalism in the world of work. In this case, the English teacher in a vocational high school teaches English. English in general and not ESP based.

\section{a. Teaching materials needed for marketing students at SMKN 01 Kota Bengkulu.}

Based on the questionnaire results, researchers needed marketing students to learn English at SMKN 1 Kota Bengkulu. The teaching materials used were school regulations and were following the curriculum from the government. However, some students said they had difficulty understanding English learning because the content of the material was considered non-specific and still general, and the content of the material was not organized, such as pictures and text.

The findings above are similar to the results of a study entitled: Analysis of ESP Needs for Tourism Study Programs at SMKN 7 Kota Bengkulu. It is concluded that the material that emphasizes vocabulary and grammar is related to 
culinary terms such as overcooked, branch, whisk, and is still general. Learning activities are emphasized speaking and reading skills. This becomes a little complicated because of the incompatibility of the material to the student's field and the unstructured content of the material so that it is difficult to understand, such as placing pictures after the text or students completing. However, in the book, there are no pictures. Another problem that is felt is student boredom because the material presented is just that and impacts boredom.

Based on the questionnaire results regarding aspects of the target need and learning need, the data showed that first, the target needs aspect in the first indicator, namely the Goal of Students, the results show that $88.2 \%$ need English learning intending to improve their English speaking skills. Furthermore, on the second target need indicator, namely Necessity, the results show that the highest score students need to improve their English to prepare them for the world of work. The third indicator is Lacks; the results show that $58.8 \%$ of students have difficulty understanding English because the language used is not specific and general. Finally, the last indicator is their Wants. The highest score shows that $76.5 \%$ of students want to understand English in vocabulary and grammar.

Based on the questionnaire results on aspects of learning needs in the first indicator, namely, Input as much as $73.5 \%$ of the original material needs in learning English. Second, the aspect of learning need, namely Procedure, showed that $79.4 \%$ of students learn English to improve speaking and dialogue using English. Third, the learning need, namely Setting the results, shows that $82.4 \%$ of students want to learn English outside the room, not only focusing in the room. Fourth, the aspect of learning need was the Teacher's role. The results show that $82.4 \%$ of students expect teachers to create a vibrant learning atmosphere in the classroom, and students are not quickly bored with learning English. The results of the questionnaire on the aspect of learning need, namely the Learner's role indicator, the results obtained showed that $73.5 \%$ of students wanted active learning in class and had discussions in English

\section{b. Students Marketing view learning English at SMKN 01 Kota Bengkulu}


Based on the interview, based on the results of interviews with five respondents and a teacher. Students have difficulty understanding English because the English used is not specific and general, and the target student needs are still relatively low. Based on interviews, based on the results of interviews with five respondents and a teacher. students have difficulty in understanding English because the English used is not specific and general.

\section{Target Needs}

Based on the results of interviews with several students, students want easy-to-understand English learning in the form of grammatical vocabulary and so on. However, students still experience are difficulties when learning English, namely because the language used is not specific. However, it is easy to reach; this is following their opinion that they have understood a few words in English books.

\section{Learning Need}

In the second aspect, namely learning need, the results obtained from interviews with researchers and students are that students need a material that does not focus on teaching materials students also hope that learning media can be in the form of audiovisual such as watching movies and listening to music through television, so students will get a chance to learn. New words and learn to improve their English skills.

Then the researcher conducted interviews with several students regarding the procedures needed by students in their learning needs. The results obtained are that students want to learn English by practising directly in class, such as by conducting dialogue while discussing in class. The researcher discussed the setting and the teacher's role to find out the need for further learning. Students said that they were bored when learning English was only done in the room, and students expected learning English to be fun in the classroom, where teachers here are required to create a vibrant and comfortable learning atmosphere. Finally, students explain their views on the learner's role. The result is that students are pretty active in class, such as during discussions and when the teacher explains the material in class. To find out the need for further learning, the researcher discussed the setting and 
the role of the teacher, the students said that they were bored when learning English was only done indoors, and the students expected learning English to be fun in the classroom where the teachers here are required to create a vibrant learning atmosphere and comfortable. Based on the questionnaires and interviews, the results of the research above were obtained:

1. Students marketing English learning activities and materials are still general and not yet available at ESP.

2. From the results of questionnaires and interviews, it is known that the English language skills most needed by marketing students are speaking. In addition, most of the respondents agree that speaking is a helpful skill to support their future work.

\section{Conclusion and Suggestion}

The result of this study is that their view of learning English is quite good because the teacher also teaches them to have an English dialogue while doing English learning activities. Then, they consider that the skills that students need are speaking in English to support their future work. Therefore, they need learning content that starts with their current needs and conditions, then continues with what they want in the future, whether it is about listening, speaking, reading, and writing. In conclusion, they need a material that is easy to understand and useful for their future work. The final product of this research is an English syllabus for 10th-grade marketing students. The researcher hopes that this study's results can help teachers make a syllabus based on the results of the research above. The researcher also hopes that the results of this research can be helpful for students who study English subjects in the marketing department.

Moreover, related to material input, based on the results of the needs analysis of students in the field of marketing that students want to practice speaking English more; they consider this skill essential for their future work. Finally, the last suggestion is related to learning activities. The result of this research is that students' needs indicate that students want various activities. Then suggestedenjoyable, relevant activities for each skill. It is also 
recommended to study outside the classroom to stimulate student activity and increase their enthusiasm for learning.

\section{References}

Atri, R, Need Analysis of ESP For Tourism Study Program At SMKN 7 Kota Bengkulu, Journal of English Education and Teaching. (2019).

Basturkmen,H, Developing Course in English for Specific Purposes, (New York: Palgrave Macmillan. ( 2010), p. 3.

Chia, H., L.,English for Specific Purposes (ESP) for Hospitality College Students and Hotel Employees in Taiwan, International Journal of Education and Research, 2, (1). (2013),46-47.

Cunningham, R, Needs Analysis for A Developmental Reading, Writing, and Grammar Course At A Private Language School In Cambodia, University of Hawai,,i at Mānoa,2015, P.3

Evan, D .English for Specific Purposes: A Holistis Review. Universal Journal of Educational Research. http://www.hrpub.org. 2015. P. 24-25

Febriatun ,L, Developing English Speaking Materials for Xth grade of Hotel Accomodation Department in SMK PI Ambarukmo 1 Sleman, A Thesis Presented as a Partial Fulfillment of the Requirements for the Attainment of the SarjanaPendidikanDegree in English Education, English Education Department Faculty of language and art yogyakarta, 2016, P.21

I Ondara Douglas, B.ED, A Need Analysis of Business English Programme for Tour Guide Diploma Students in Kenya, 1. 5. (2013), 71-73.

Jeff Tanner, Dkk, Marketing Principles,( Boston: Flat World Knowledge, 2012), p. 8 Jeff Tanner, Dkk, Marketing Principles,( Boston: Flat World Knowledge, 2012), p. 8

Rita, Karmila. Analisis Kebutuhan Pembelajaran Bahasa Inggris Pada Mahasiswa Kelas Kariawan . 4.1 ( 2019).

Pratiwi,R, Dkk , Analisa Kebutuhan Buku Ajar Bahasa Inggris SMK Jurusan Usaha Perjalanan Wisata. http://www.jurnal.unublitar.ac.id/ index.php/brilliant. 29 February 2020 P. 19

Pongjumpa, S. A survey of The Needs of English Proficiency of Five Star Hotels' Staff and Refresentatives in Bangkok and The Aspects of Needs Reffering to Hotel English and General English. Thamsat University Bangkok Thailand. 1. 5.(2011), 91-93. 
Patriana, S, Syllabus of Vocational High School Based on ESP Approach ISSN: 1411-3031, 15 .02. (2015).

Rizal, Syamsul. Analisis Kebutuhan Bahan Ajar Bahasa Inggris Iain Bengkulu melalui Studen't Need Analysis. 232- 252 (2019).

Sugiyono. Metode Penelitian Pendidikan: Pendekatan Kuantitatif, Kualitatif, dan R\&D, (Bandung: Alfabeta, 2014), p.1

Tenri, A., Amin,. M.R., Rahman, A., Haryanto, \& Basri, M. The Students` Needs in Developing Learning Materials for Speaking Skills in Indonesia, Journal of Education and Practice, 4. 17. (2013), 171

Tom Hutchinson, Dkk. English for Specific Purposes p. 55-61 Richards Syllabus of Vocational High School Based on ESP Approach ISSN: 1411-3031, 15.02. (2015)

Tonić, A. Triangulation of Needs Analysis in English for Tourism Purposes.Osnovna šola Toma Brejca amnik, 1.3, (2010).52-53.

Waters, H. Syllabus of Vocational High School Based on ESP Approach ISSN: 1411-303 .15 .02. 9 (2015).

Waters. H. English for Specific Purposes: A Holistis Review. Universal Journal of Educational Research. P. 24-25. http://www.hrpub.org. 201 